\title{
Assessment of leptin, c-reactive protein and lipid levels in children and adolescents with myelomeningocele
}

\section{Ocena stęzenia leptyny, białka ostrej fazy i lipidów u dzieci i młodzieży z przepukliną oponowo-rdzeniową}

\author{
Bożena Okurowska-Zawada', Agata Korzeniecka-Kozerska², Wojciech Kułak', Janusz Wojtkowski \\ ${ }^{1}$ Klinika Rehabilitacji Dziecięcej z Ośrodkiem Wczesnej Pomocy Dzieciom Upośledzonym „Dać Szansę” \\ Uniwersytetu Medycznego w Białymstoku \\ ${ }^{2}$ Klinika Pediatrii i Nefrologii Uniwersytetu Medycznego w Białymstoku
}

DOI: 10.20966/chn.2016.51.381

\section{STRESZCZENIE}

Wstęp. Rozwój otyłości oraz miażdżycy może rozpocząć się już w wieku dziecięcym szczególnie u pacjentów z ograniczoną aktywnością ruchową w przebiegu przepukliny oponowo-rdzeniowej (MMC). W diagnostyce, oprócz oznaczenia lipidogramu, stężenia glukozy, białka ostrej fazy (CRP), praktyczne znaczenie ma ocena oznaczonego stężenia leptyny w surowicy krwi. Celem pracy była ocena powyższych wskaźników u dzieci i młodzieży z MMC w zależności od skali Hoffera. Metoda. Badaniami objęto 84 pacjentów z MMC w wieku od 7 do 17 lat. Wykonano pomiary masy i wysokości ciała, oznaczono stężenia: leptyny, oceniono stan gospodarki lipidowej oraz glikemię i CRP, witaminy $\mathrm{D}_{3}$, białka całkowitego i albumin. Wyliczono wskaźniki: BMI. Wyniki. W ocenianej grupie pacjentów 29 pacjentów poruszało się samodzielnie (IV wg skali Hoffera), a 34 osoby poruszały się na wózkach (I wg skali Hoffera) przy średniej wartości skali Hoffera 2,45. Średnie stężenie leptyny w grupie badanej wynosiło $9,45 \mathrm{ng} / \mathrm{ml}$ i było wyższe niż w grupie kontrolnej 5,85 ng/ $\mathrm{ml}$. Stężenia leptyny zależały istotnie statystycznie od wieku (p $=0,000)$; wzrostu $(p=0.000)$; poziomu aktywności ruchowej wg klasyfikacji Hoffera $(p=0.0017)$; BMI $(p=0.000)$; białka całkowitego $(p=0,0306)$. Wnioski. Wysokie stężenia leptyny u dzieci z przepukliną oponowo-rdzeniową z nadmiarem masy ciała mogą być wskaźnikiem rozwoju zespołu metabolicznego. Dzieci z otyłością oraz wspótistniejącymi zaburzeniami metabolicznymi powinny być objęte szczególną opieką ze względu na możliwość wystąpienia wczesnych zmian miażdżycowych

Słowa kluczowe: przepuklina oponowo-rdzeniowa, leptyna, otyłość

\section{ABSTRACT}

Introduction. Development of obesity and atherosclerosis can begin at a young age, particularly in patients with limited mobility as a result of myelomeningocele (MMC). In diagnostics, in addition to lipidogram, glucose and C-reactive protein (CRP) levels, the concentration of leptin in blood serum has practical importance. The aim of the study was to assess the above indicators in children and adolescents with MMC depending on Hoffer's scale. Method. We studied 84 patients with MMC aged 7-17 years. The following were measured: weight, height, leptin levels, lipid metabolism, glycemia, CRP, vitamin $\mathrm{D}_{3^{\prime}}$ total protein and albumin. BMI was calculated. In the assessed group of patients 29 patients moved independently (IV on Hoffer's scale) and 34 patients used a wheelchair (I on Hoffer's scale) with a mean value of 2.45 on Hoffer's scale. Results. Mean leptin level in the study group was $9.45 \mathrm{ng} / \mathrm{mL}$ and was higher compared with the control group $(5.85 \mathrm{ng} / \mathrm{mL})$. Leptin levels statistically significantly depended on age $(p=0,000)$; height $(p=0.000)$; level of physical activity according to Hoffer's classification $(p=0.0017) ; B M I(p=0.000)$; total protein $(p=0.0306)$. Conclusion: High leptin levels in children with MMC with excess body mass can be an indicator of metabolic syndrome development.

Key words: myelomeningocele, leptin, obesity

\section{INTRODUCTION}

Myelomeningocele (MMC) affects approximately 1 in every 1,000 newborns, making it the second (after Down syndrome) most common birth defect. Statistics show that the incidence of MMC ranges between 2.05 and 2.68 per 1,000 live births in Poland [1]. The occurrence of complications in the form of limb fractures below the level of spinal cord injury is associated with bone trophic impairment, mainly due to different movement and activity pattern (predominance of sedentary lifestyle, significantly limited movement, absence of lower extremity loading) [2]. Incre- ased fat deposition and body weight can lead to decreased physical activity in the affected children. About half of MMC patients use a wheelchair. Obesity, which is common among MMC children, can be a significant risk factor for type 2 diabetes and atherosclerosis. Reports on risk factors for atherosclerosis in children with MMC are sparse [3]. Furthermore, it is believed that there are three SNP genes associated with glucose metabolism and obesity [4]. Leptin, a hormone, is produced mainly in adipocytes and placental trophoblast cells. It bears high structural simila- 
rity to the cytokine family. Structurally, leptin is a protein composed of 167 amino acids. Since it is synthesized in fat tissue adipocytes, it belongs to the group of biologically active adipokines (proteins). The hormone acts via leptin receptors located mainly in the hypothalamus. Once leptin binds to hypothalamic receptors, neurons cease to produce a neurotransmitter - neuropeptide Y, which stimulates appetite. Thus, the hormone reduces hunger and stimulates the sympathetic nervous system. Impaired production of this hormone or insensitivity of its receptors often leads to weight gain and obesity [5-8]. The leptin-encoding gene is located on chromosome $7 \mathrm{q} 31.3$ and is referred to as the obesity gene [9]. CRP measurement is used to monitor the course or the risk of inflammatory diseases (bacterial or viral infections). Additionally, it is increasingly used to assess the risk of cardiovascular incidents [10]. Pediatric MMC not only leads to physical disability but can also cause premature development of obesity and atherosclerosis in this patient population.

The aim of this study was to determine whether increased levels of leptin occurred in a group of MMC children with varying degrees of motor impairment according to Hoffer's classification, as well as to determine whether there is a relationship between leptin levels and somatic nutritional status parameters and biochemical indicators of lipid metabolism and glycemia.

\section{METHOD}

\section{Subjects}

The study was conducted in a group of 84 children with MMC (46 girls, 38 boys) aged 7-17 years (mean age 9.1 years), remaining under the care of the Department of Pediatric Rehabilitation and the Department of Pediatrics and Nephrology at the Medical University of Bialystok. Each child underwent physical examination with anthropometric measurements; movement disorders were assessed using Hoffer's classification; BMI was calculated based on body weight and height.

Inclusion criteria: patients with MMC. Exclusion criteria: patients with non-MMC; acute infection; hsCRP values higher than $10 \mathrm{mg} / \mathrm{L}$.

Patients were divided into 4 groups according to Hoffer's scale which assesses physical activity (I - wheelchairdependent patients, II - therapeutic walkers, III - household walkers, IV - community walkers). Additionally, patients were divided according to the level of lesion based on the neurosurgical data into three groups: 1-thoraco-lumbar (Th-L), 2- lumbar-sacral (L-S), 3- sacral (S).

High-Sensitivity CRP is a test that allows precise determination of low CRP levels not exceeding positive values for inflammation detected using standard CRP testing. Hs-CRP higher than $10 \mathrm{mg} / \mathrm{l}$ indicates the need to implement diagnostics for conditions other than cardiovascular diseases. The control group included 20 healthy children with median age 9.12 years $(1.42-17.75)$ with no heart or endocrine diseases.

\section{Biochemistry}

Biochemical analyses were performed at the Department of Pediatric Laboratory Diagnostics of the University of Children's Hospital in Białystok, Białystok, Poland. Morning fasting venous blood samples were collected from every child for the measurement of the bochemical parameters. The following tests were performed: 1. Assessment of leptin levels using the enzyme-linked immunosorbent assay (ELISA, BioSo urce). Acceptable leptin levels 1-100 $\mathrm{ng} / \mathrm{mL}$. 2. Serum levels of hs-CRP in children with MMC. 3. Fasting blood tests for total cholesterol, HDL and LDL fractions, triglycerides and glycemia, in accordance with the accepted laboratory methods.

Normal distribution of data was evaluated by a Kolmogorov-Smirnov test. Data were not normally distributed. $(\mathrm{d}=0.262 ; p<0.01)$. Mean test results were compared using the Wilcoxon test. Correlations between leptin levels and variables were assessed using multiple regression analysis. Statistical analyses were done using STATISTICA 10 PL software. A level of $p<0.05$ was considered statistically significant. The Bioethics Committee of the Medical University of Bialystok approved the study.

\section{RESULIS}

The study was conducted in a group of 84 children (46 girls, 38 boys) aged $7-17$ years (mean age 9.1 years) with MMC. In the assessed group of patients, 29 patients moved independently (IV on Hoffer's scale), and 34 patients used a wheelchair (I on Hoffer's scale), with a mean value of 2.448 on Hoffer's scale. Twenty seven patients (31\%) had spinal lesion at thoraco-lumbar level, 52 (59\%) had at lumbar-sacral, and $9(10 \%)$ at sacral level.

Overall, children with MMC were overweight and healthy children had a normal body weight. Mean BMI values were $19.08 \pm 10.03$ in children with MMC and 14.80 \pm 8.05 in the control group; however, there was no statistically significant difference ( $p=0.102$, Wilcoxon test) Mean leptin values were $9.44 \pm 12.41 \mathrm{ng} / \mathrm{mL}(0.45-52.77)$ in children with MMC and $5.85 \pm 8.23 \mathrm{ng} / \mathrm{ml}(0.77-29.41)$ in the control group. Leptin levels were higher in children with MMC compared with the control group; however, there was no statistically significant difference $(p=0.398$, Wilcoxon test). A comparison of biochemical parameters in children with MMC and the control group revealed only one significant ( $p=0.033$ ) difference related to hCRP between MMC and controls (tab. I).

There was a statistically significant correlation between leptin levels and patient age, height, physical activity according to Hoffer's classification, BMI, and total protein. Details are shown in tab. II.

\section{DISCUSSION}

The study included 84 patients with MMC aged 7-17 years. In the assessed group of patients 29 patients moved independently (IV on Hoffer's scale), and 34 patients used a wheelchair (I on Hoffer's scale), with a mean value of 2.45 on Hoffer's scale. Mean leptin level in the study group 
Table I. Comparison of biochemical blood parameters in children with MMC and controls

\begin{tabular}{|c|c|c|c|c|c|}
\hline Parameters & Mean & Min. & Max. & SD & P-value \\
\hline Glucose MMC (mg/ml) & 88.07 & 69.00 & 146.00 & 13.15 & \multirow{2}{*}{0.465} \\
\hline Glucose control (mg/ml) & 86.08 & 75.00 & 107.00 & 8.83 & \\
\hline TG MMC (mg/ml) & 88.51 & 30.00 & 302.00 & 52.47 & \multirow{2}{*}{0.176} \\
\hline TG control (mg/ml) & 94.45 & 56.00 & 243.00 & 52.83 & \\
\hline Cholesterol MMC (mg/ml) & 174.02 & 106.00 & 229.00 & 27.05 & \multirow{2}{*}{0.483} \\
\hline Cholesterol control (mg/ml) & 169.63 & 106.00 & 203.00 & 26.03 & \\
\hline HDL MMC (mg/ml) & 54.95 & 39.00 & 83.00 & 11.89 & \multirow{2}{*}{0.310} \\
\hline HDL control (mg/ml) & 50.91 & 39.00 & 6400 & 8.51 & \\
\hline LDL MMC (mg/ml) & 101.35 & 26.00 & 160.00 & 26.00 & \multirow{2}{*}{0.498} \\
\hline LDL control (mg/ml) & 92.18 & 10.00 & 151.00 & 39.97 & \\
\hline hsCRP MMC (mg/L) & 12.7164 & 2.72 & 16.72 & 2.54 & \multirow{2}{*}{$0.033^{a}$} \\
\hline hsCRP control (mg/L) & 7.09143 & 1.80 & 4.53 & 1.27 & \\
\hline
\end{tabular}

Abbreviations: HDL - high-density lipoproteins; LDL - low-density lipoproteins; MMC - myelomeningocele; TG - triglycerides; hsCRP - high-sensitivity CRP; SD - standard deviation.

a Significant $p<0.05$.

Table II. Correlations between leptin levels and Hoffer's scale, sex, height, BMI, laboratory parameters in children and adolescents with MMC

\begin{tabular}{llc}
\hline Variables & beta & P value \\
\hline Leptin vs Hoffer & -0.395 & $<0.001$ \\
\hline Leptin vs. Age & 0.432 & $<0.001$ \\
\hline Leptin vs. Sex & -0.150 & 0.164 \\
\hline Leptin vs. Height & 0.524 & $<0.001$ \\
\hline Leptin vs. BMl & 0.669 & $<0.001$ \\
\hline Leptin vs. Vitamin D3 & 0.044 & 0.683 \\
\hline Leptin vs. Glucose & 0.210 & 0.054 \\
\hline Leptin vs. TG & 0.111 & 0.326 \\
\hline Leptin vs. Total Cholesterol & 0.131 & 0.345 \\
\hline Leptin vs. HDL & 0.009 & 0.934 \\
\hline Leptin vs. LDL & 0.001 & 0.950 \\
\hline Leptin vs. albumin & 0.186 & 0.284 \\
\hline Leptin vs. total protein & 0.320 & $<0.05$ \\
\hline Leptin vs. hsCRP & 0.189 & 0.301 \\
\hline
\end{tabular}

Abbreviations: BMI - body mass index; hsCRP - high-sensitivity CRP; HDL - high-density lipoproteins; LDL - low-density lipoproteins; MMC - myelomeningocele; TG - triglycerides. 
was $9.45 \mathrm{ng} / \mathrm{mL}$ and was higher compared with controls $(5.85 \mathrm{ng} / \mathrm{mL})$. There was a statistically significant relationship between leptin levels and the level of physical activity according to Hoffer's classification; height, BMI, total protein and hsCRP. According to WHO, the normal BMI range is 5 th percentile to less than the 85 th percentile $[11,12]$. A strong correlation between BMI and the amount of body fat tissue and a weaker correlation with height compared with other indicators was considered by the WHO to be an essential element of the assessment of the protein-energy nutritional status. BMI allows to determine body fat levels. Nutritional status can be assessed based on BMI: malnutrition (low fat content), overweight or obesity (excessive fat content) [13]. Mean BMI in the assessed group of children with MMC was $19 \mathrm{~kg} / \mathrm{m}^{2}$, including 20 patients with BMI over $25 \mathrm{~kg} / \mathrm{m}^{2}$. It is currently believed that genetic factors account for $30-40 \%$ of the obese phenotype, while $60-70 \%$ are other factors $[14,15]$. The gene regulating leptin production and secretion is well-known. Leptin is a protein produced by fat cells, which controls hunger in the hypothalamus. Elevated body fat mass increases plasma leptin levels, thus reducing hunger and producing a feeling of satiety. This system determines an individual level of sensitivity to a positive energy balance via a tendency for excessive fat tissue accumulation and reduced metabolic rate $[16,17]$. It seems that increased leptin levels in obese patients are due to excess adipose tissue producing this hormone [16, 17].

Kulińska-Szukalska [18] investigated correlations with biochemical indicators in a group of overweight and obese children and showed positive correlations between hormone levels and the levels of triglycerides and glucose. These correlations were not statistically significant in the assessment of patients with MMC. Furthermore, the author [18] observed a tendency for correlations (without statistical significance) between leptin levels and HDL-cholesterol as well as a similar, yet negative correlation with total cho- lesterol. In our study, statistically significant correlations were demonstrated between leptin levels and total protein.

Wouters et al. [19] found a positive correlation between leptin levels and BMI. Similarly, we also found a statistically significant correlation in the assessed group of patients with myelomeningocele. Our findings are in line with numerous reports in the literature on correlations between leptin levels and BMI [20, 21].

Atherosclerosis in children and adolescents is usually asymptomatic, therefore no clear diagnostic criteria have been developed so far. Assessment of serum cardiovascular risk factors (e.g. levels of lipidogram components, glucose and C-reactive protein - CRP) may be also useful [22]. CRP produced in the liver due to the effects of interleukin 6 is a good marker of inflammation. Apart from its typical use in the assessment of inflammation during infections, the assessments of states predisposing to atherosclerosis is also recommended. There is a positive correlation between CRP levels and weight, BMI, insulin and TG levels, as well as a negative correlation with HDL cholesterol [23]. Its increased levels are found in children with type 1 diabetes [24], obesity, and metabolic syndrome [25]. The only significant difference between MMC and controls was found for hCRP. In our study, there was no significant correlation between total cholesterol, sex, and other biochemical parameters. These results are in agreement with the previous studies [26-28].

In conclusion, high leptin levels in MMC children with excess body mass can be an indicator of metabolic syndrome development. Metabolic disorders observed in our patients indicate the need for early primary and secondary prevention aimed at reducing excess body mass through universal education (mainly on lifestyle changes) as well as special medical care targeted at obese pediatric patients as a group at risk for multiple health problems. The lack of correlation between serum C-reactive protein levels and lipid values may indicate an absence of both inflammation and the risk of the atherosclerotic process.

\section{REFERENCES}

[1] Grossman J., Skórzak B.: Rehabilitacja dzieci z przepukliną oponowordzeniową okolicy lędźwiowo-krzyżowej. [w:] Kwolek A. (red.): Rehabilitacja Medyczna. Urban\& Partner, Wrocław 2003.

[2] Okurowska-Zawada B., Konstantynowicz J., Kułak W., et al.: Assessment of risk factors for osteoporosis and fractures in children with meningomyelocele. Adv Med Sci 2009; 54: 247-252.

[3] Rendeli C., Castorina M., Ausili E., et al.: Risk factors for atherogenesis in children with spina bifida. Childs Nerv Syst 2004; 20: 392-396.

[4] Washburn R.A., Figoni S.F.: High density lipoprotein cholesterol in individuals with spinal cord injury: the potential role of physical activity. Spinal Cord 1999; 37: 685-695.

[5] Hanai K., Babazono T., Takagi M., et al.: Obesity as an effect modifier of the association between leptin and diabetic kidney disease. J Diabetes Investig 2014; 5: 213-220.

[6] Alsmadi 0., Melhem M., Hebbar P., et al.: Leptin in Association With Common Variants of MC3R Mediates Hypertension. Am J Hypertens 2014; 27: 973-981.

[7] Sayın 0., Tokgöz Y., Arslan N.: Investigation of adropin and leptin levels in pediatric obesity-related nonalcoholic fatty liver disease. J Pediatr Endocrinol Metab 2014; 27: 479-484.

[8] Houseknecht K., Baile C., Matteri R., et al.: The biology of leptin: a review. J Anim Sci 1998; 76: 1405-1420.

[9] Ahima R.S., Flier J.S.: Leptin. Annu Rev Physiol 2000; 62: 413-437.

[10] Strang F., Schunkert H.: C-Reactive Protein and Coronary Heart Disease: All Said-Is Not It? Mediators Inflamm 2014; 2014: 757123.

[11] Krzyżaniak A., Krawczyński M., Walkowiak J.: Wskaźniki proporcji wagowo-wzrostowych w populacji dzieci i młodzieży miasta Poznania. Pediatr Prakt 2000; 8: 355-364. (Polish)

[12] Pupek-Musialik D., Kujawska-Łuczak M., Bogdański P.: Otyłość i nadwaga - epidemia XXI wieku. Przew Lek 2008; 1: 117-123.

[13] Farpour-Lambert N.J, Baker J.L, Hassapidou M., et al.: Childhood Obesity Is a Chronic Disease Demanding Specific Health Care-a Position Statement from the Childhood Obesity Task Force (COTF) of the European Association for the Study of Obesity (EASO). Obes Facts 2015; 8: 342-349.

[14] Chesi A., Grant S.F.: The Genetics of Pediatric Obesity. Trends Endocrinol Metab 2015; 26: 711-721.

[15] Silventoinen K., Rokholm B., Kaprio J., et al.: The genetic and environmental influences on childhood obesity: a systematic review of twin and adoption studies. Int J Obes (Lond) 2010; 34: 29-40.

[16] Russell C.D., Ricci M.R., Brolin R.E., et al.: Regulation of the leptin content of obese human adipose tissue. Am J Physiol Endocrinol Metab 2001; 280: 399-404. 
[17] Friedman J.M.: Leptin and the regulation of body weight. Keio J Med 2011; 60: 1-9.

[18] Kulińska-Szukalska K., Chlebna-Sokół E.: Hiperleptynemia u dzieci z nadmiarem masy ciała. Endokrynol Ped 2012; 3: 41-48.

[19] Woutears M., Mertens I., Considine R., et al.: Are leptin levels dependent on body fat distribution in obese men and women. Eat Weight Disord 1998; 3: 124-130.

[20] Schoppen S., Riestra P., García-Anguita A., et al.: Leptin and adiponectin levels in pubertal children: relationship with anthropometric variables and body composition. Clin Chem Lab Med 2010: 48: 707-711.

[21] Madeira I.R., Carvalho C.N., Gazolla F.M., et al.: Impact of obesity on metabolic syndrome components and adipokines in prepubertal children. J. Pediatr 2009; 85: 261-268.

[22] Beauloye V., Zech F., Tran H.T., et al.: Determinants of early atherosclerosis in obese children and adolescents. J Clin Endocrinol Metab 2007; 92: 3025-3032.
[23] Quijada Z., Paoli M., Zerpa Y., et al.: Lanes R: The triglyceride/HDLcholesterol ratio as a marker of cardiovascular risk in obese children; association with traditional and emergent risk factors. Pediatr Diabetes 2008; 9: 464-471.

[24] Reinehr T., Kiess W., de Sousa G., et al.: Intima media thickness in childhood obesity: relations to inflammatory marker, glucose metabolism, and blood pressure. Metabolism 2006; 55: 113-118.

[25] Soriano-Guillén L., Hernández-García B., Pita J., et al.: High-sensitivity C-reactive protein is a good marker of cardiovascular risk in obese children and adolescents. Eur J Endocrinol 2008; 159: R1-4.

[26] Byrnes S.E., Baur L.A., Bermingham M., et al.: Leptin and total cholesterol are predictors of weight gain in pre-pubertal children. Int $\mathrm{J}$ Obes Relat Metab Disord 1999; 23: 146-150.

[27] Savoye M., Dziura J., Castle J., et al.: Importance of plasma leptin in predicting future weight gain in obese children: a two-and-a-half-year longitudinal study. Int J Obes Relat Metab Disord 2002; 26: 942-946.

[28] Holm J.C., Gamborg M., Kaas-lbsen K., et al.: Time course and determinants of leptin decline during weight loss in obese boys and girls. Int J Pediatr Obes 2007; 2: 2-10. 